\title{
Challenging the Good Life: An Institutional Theoretic Investigation of Consumers' Transformational Process Toward Sustainable Living
}

\author{
Derek Ezell ${ }^{1}$. Victoria Bush ${ }^{2} \cdot$ Matthew B. Shaner $^{2} \cdot$ Scott Vitell $^{2} \cdot$ Jiangang Huang ${ }^{2}$
}

Received: 29 September 2020 / Accepted: 24 November 2021 / Published online: 28 January 2022

(c) The Author(s), under exclusive licence to Springer Nature B.V. 2021

\begin{abstract}
In pursuit of sustainable living, ethics researchers as well as consumers themselves have challenged the status quo of consumption as an institution. Fueled by global economic, environmental, and societal concerns, responsible consumption has become an integral part of the sustainability and consumption ethics literature. One movement toward sustainability consists of confining living space into a smaller ecological footprint. Although motivations for such a lifestyle have been examined, little research has investigated the process of how members of the tiny house movement reconfigure learned consumption practices. This study investigates tiny house dwellers' transformational experiences through the theoretical lens of contemporary institutional change. Qualitative analysis reveals that these challengers of the status quo face significant normative, regulatory, and cognitive hurdles. However, by engaging in sensemaking, validation, and change agency practices, tiny house dwellers have attempted to legitimize a new way of sustainable living that can be in conflict with existing institutions. Implications and future research are discussed in terms of how examining institutional change processes can be a vital part of ethics and sustainability research. Implications are also provided for how marketing organizations can consider modifying their market offerings to capitalize on this segment of society.
\end{abstract}

Keywords Sustainability $\cdot$ Institutional change $\cdot$ Ethics logic conflict $\cdot$ Consumer responsibility

\section{Introduction}

Editors at the Journal of Business Ethics are recused from all decisions relating to submissions with which there is any identified potential conflict of interest. Submissions to the Journal of Business Ethics from editors of the journal are handled by a senior independent editor at the journal and subject to full double blind peer review processes.

Victoria Bush

vbush@bus.olemiss.edu

Derek Ezell

dezell1@utm.edu

Matthew B. Shaner

mshaner@bus.olemiss.edu

Scott Vitell

svitell@bus.olemiss.edu

Jiangang Huang

jhuang@bus.olemiss.edu

1 Department of Management, Marketing, and Information Systems, The University of Tennessee at Martin, Business Administration Building, Martin, TN 38238, USA

2 School of Business, University of Mississippi, University, Oxford, MS 38677, USA
I went to the woods because I wished to live deliberately...

Henry David Thoreau (1854), Walden.

In a global economy beleaguered by energy crises, environmental deprivation, financial debt, and health calamities, not to mention the COVID-19 virus pandemic, academic researchers, organizations, and individuals are contesting the typical consumption status quo by reevaluating their standard of living (Albinsson \& Perera, 2012; Markman, 2020). Critics state that the Western economy promotes instant gratification while at the same time encourages environmental, social, and fiscal responsibility. These concepts can be diametrically opposed to each other and in time, "although the connections between how people live and the ecological system are made opaque by the complexity of today's economy, the simple truth is that consumption patterns cannot continue at their current rate" (Lim, 2017, p. 69). Thus, scholars have emphasized seeking a sustainable future for 
marketing ethics and consumer behavior as an important and vital research agenda (Davies et al., 2020).

According to Sheth and colleagues (2011), sustainability requires a paradigm shift toward more responsible behavior from consumers, or "...consciousness in thought and behavior about the consequences of consumption" (p. 27). One group of individuals that has embraced such consciousness adheres to Thoreau's concept of "living deliberately" - by transforming their living space into a smaller ecological footprint. By limiting their possessions and living domicile, members of this segment of society belong to the tiny house movement. Tiny houses are defined as dwellings, whether on foundation or wheels, smaller than 400 square feet that include a kitchen, bath, sleeping, and living area (Mangold $\&$ Zschau, 2019). These dwellings are transportable but not in the sense of recreational vehicles (RVs) or caravans. They are designed to be stand-alone structures that must adhere to a number of typical building codes for larger houses (including insulation, exterior trim, steeped roofs, and weather resistant windows) that vary by country, region, and state (e.g., Kaufmann, 2015). Tiny houses provide the opportunity for ownership rather than renting a room in a house, detached dwelling, or a small apartment/flat.

Communities of tiny house dwellers have been part of a social movement to eschew the accepted logic that owning a large house (typically with a mortgage) full of material possessions reflects achievement and status (Chadwick, 2019). Although this movement has been in existence for some time (cf., Thoreau, 1854), this lifestyle has gained visibility in recent years with Sarah Susanka's tenth anniversary edition of The Not So Big House: A Blueprint for the Way We Really Live (2009), a seminal publication that advocates quality before quantity in small house living. The allure of tiny houses varies from person to person, but often comes from its novelty in providing mobility, financial freedom, and flexibility. Concurrently, housing market fluctuations, increased cost of rent, financial debt, environmental concerns, and healthcare uncertainty, have made living in a tiny house an attractive alternative. In fact, since the worldwide COVID19 pandemic began in 2020, tiny houses have also grown in popularity as a solution to quarantine living (Chang, 2020).

Information sources such as websites, blogs, and streaming tv shows (e.g., www.tinyliving.com, www.tinyhouseb log.com, Tiny House Hunters on Discovery Channel TV in the U.S., and featured on The One Show on BBC, UK), tout the benefits of those who have embraced this lifestyle. Such sources have helped current and future dwellers learn about a new way of consumption which has made them more aware of their environmental impact, fiscal responsibility, and social consciousness. (Mangold \& Zschau, 2019).

However, even as far back as Walden in 1854, Thoreau was accused of being an escapist and tax evader, and tiny house dwellers also face some of the same criticisms. These individuals have challenged the status quo of complacency that many consumers have invested in financially and emotionally by living beyond their means (Diguette, 2017). Participating in such a transition to a tiny house can be viewed as in direct conflict with the logic of consumption as an institution. Institutions are rules, norms, beliefs, and systems of meaning that help social groups overcome limits in rational decision-making (Vargo \& Lusch, 2016). These "cognitive, normative, and regulative structures ... provide stability and meaning to social behavior." (Scott, 1995, p. 33). As such, tiny house dwellers have the potential to confront the institution of consumption and develop new structures of meaning.

The purpose of this study is to investigate the process of how tiny house dwellers come into conflict, transform, and reconfigure their consumption practices for sustainable living. Using institutional change theory as our foundation, we conducted qualitative interviews with members of this community. Text analysis provided a rich description of how these tiny house dwellers practice an alternative lifestyle that conflicts with social norms, purchase and ownership decisions, and community regulations. The practices emergent from our analysis were incorporated into a conceptual model that demonstrates how sensemaking, validation, and change agency have the potential to legitimize a new movement toward more sustainable consumption.

This research contributes to the consumer ethics and sustainability literature in several ways. First, marketing and ethics researchers have advocated that our discipline concentrate on alternative consumption patterns and marketplaces that have the capacity to improve future generations (Davies et al., 2020; Davis et al., 2016; Giesler \& Veresiu, 2014). We contribute to this stream of research by investigating how tiny house dwellers alter their learned practices toward more sustainable consumption. Second, we contribute to institutional change theory by examining how consumers attempt to legitimize an alternative market instead of focusing on how marketers legitimize their product offerings (cf, Scaraboto \& Fischer, 2013). By doing so at this micro-level, consumers have the potential not only to demand action from corporations, but also be an integral part of institutional change toward responsible consumption (cf., Geisler \& Veresiu 2014; Schlaile et al., 2018; Vitell, 2015). Third, ethics scholars have called for the integration of ethics and institutional theory to understand logic conflicts (cf. Nielsen \& Lockwood, 2018; Nielsen \& Massa, 2013). We investigate how tiny house dwellers redefine the logic of their living domicile that conflicts with accepted norms, cognitions, and regulations of consumption. Thus, we answer the call for more research focused on sociocultural change (Dolbec \& Fischer, 2015; Geisler \& Thompson, 2016).

What follows is a discussion of relevant literature to set the stage for our investigation and analysis of tiny house dwellers' change process. Subsequently, the methodological 
approach to our text analysis is overviewed. Our findings are then discussed in terms of how the transitional process to tiny house living reveals significant institutional change practices within the logics of social community, marketplace interactions, and civic engagement. These practices are then incorporated into a conceptual model that demonstrates how sensemaking, validation, and change agency can legitimize a unique form of sustainable living.

\section{Sustainability and Responsible Consumption}

The concept of sustainability has been widely reviewed and debated in terms of how marketing and consumer researchers can move this important field of study forward. The very definition of sustainability reflects its fragmented nature that cuts across environmental, economic, and social disciplines (cf., Davies et al., 2020). Perhaps the most general and holistic definition of sustainability stemmed from the Brundtland Commission via the World Commission on Environment and Development (WCED) (1987): to "meet the needs of the present without compromising the ability of future generations to meet their own needs."

In marketing, sustainability has been defined from the perspective of exchange of value - "the strategic creation, communication, delivery, and exchange of offerings that produce value through consumption behaviors, business practices, and the marketplace, while lowering harm to the environment and ethically and equitably increasing the quality of life and well-being of consumers and global stakeholders, presently and for future generations" (Lunde, 2018, p. 10). This definition has been criticized for focusing too much on ethical, pro-environmental decision-making behavior and too little on how to actually change or transform behavior. Davies et al.'s (2020) in-depth critique of sustainability advocates moving toward a more systemic approach by embracing multiple alternative theoretical perspectives and interpretative analyses that focus on transformative consumer research (TCR) (e.g., Tadajewski et al., 2014).

Researchers in TCR have advocated for new perspectives on how to transform or even create sustainable consumers, if not citizens (Barrett et al., 2016). Indeed, the very word "consumer" implies a one-sided capitalistic mindset that could impede progress toward sustainability. However, TCR has focused primarily on how marketers can effect such change, whereas less research has focused what the consumer can do. As Schlaile and colleagues (2018) reiterate, it is assumed that businesses have the responsibility to effect change, yet consumers have the power to change questionable practices as well. We concur with this perspective that "citizens as consumers have the transformative capacity to create a more sustainable society..." (Davies et al., 2020, p.
2918). Thus, creating a sustainable future does not always emanate from the top-down (i.e., corporate social responsibility), but can originate from the bottom-up as consumers also bear some responsibility (Scaraboto \& Fischer, 2013; Vitell, 2015).

Responsible consumption has typically been referred to as a moral obligation to be aware of the impact of one's consumption practices on the environment, health, and society (Schor, 1998). As elicited by Thoreau many years ago, one aspect of responsible consumption consists of shifting away from a materialistic lifestyle toward a more simplistic one that is "outwardly simple and inwardly rich" (Elgin \& Mitchell, 1977, p. 13). Such behavior has been examined in the movement toward voluntary simplicity (McDonald et al., 2006), where individuals choose to limit spending on materialistic "goods and services...to cultivate non-materialistic sources of satisfaction and meaning" (Etzioni, 1998, p. 620). In the case of tiny house dwellers, these individuals are dramatically simplifying, reconstructing, and limiting their consumption. Yet, the actual transition toward this lifestyle is not without conflict and its investigation is warranted since it challenges the institutional status quo of commonly accepted materialistic consumption patterns.

\section{Institutional Conflict and Change}

Institutions are rules, norms, beliefs, and systems of meaning that help a social group overcome limits in rational decision-making (Vargo \& Lusch, 2016) so that social groups can make sense of their environment without being cognitively overloaded. As a result, these institutions have logics (Nielsen \& Lockwood, 2018) that "provide meaning to daily activities, organize time and space, and reproduce...experiences" (Thornton et al., 2012, p. 2). Institutional theory posits three main pillars that provide stability and meaning to social behavior - the normative, regulative, and cognitive pillars (Scott, 1995). These three pillars may conflict with one another which can create a window of opportunity for institutional change (Nielsen \& Lockwood, 2018). Although the current tiny house movement is not as solidified as older, more established social systems, it offers an opportunity to explore transitions in the logic of consumption, as individuals seek to reshape their context from the established to the new.

The normative pillar within institutional theory consists of the values and norms held by a social group and specifies how things should be done, who holds specific roles within a group, what individual actors' goals and objectives should be, and how they should go about pursuing those goals (Scott, 1995). In terms of the household setting, these normative expectations could include such rituals as housewarming gifts, domestic gender roles, and 
entertaining at home. Normative structures tend to be more morally legitimate and are more likely to be deeply internalized than formal, codified authority structures (Doherty et al., 2014). The regulative pillar consists of those more formal rules and regulations in place to compel or constrain behavior, including rulemaking, rule monitoring, and sanctioning. As Scott (1995) notes, this pillar may operate through formal, explicitly codified mechanisms (e.g., local housing and zoning laws), but they can also be informal (e.g., shunning or shaming those who do not play by the "rules"). Finally, the cognitive pillar relates to how people interpret the nature of reality, the frames through which they interpret objects and activities (e.g., valuing possessions, consumption, and ownership), and how they ascribe shared meaning to the stimuli of everyday life (Scott, 1995). Each of these three pillars contributes to a sense of legitimacy, and new institutions are difficult to create and maintain without a collective shared sense of legitimacy (Scaraboto \& Fischer, 2013; Scott, 1995).

As some authors have noted in the institutional paradigm, the role of the individual has often been portrayed in two ways: either that of a mindless actor with little agency or choice in his or her behaviors, or as a heroic agent of change who single-handedly brings about new institutional structures (Garfinkel, 1967; Scaraboto \& Fischer, 2013; Strang \& Sine, 2002). In this micro view, institutions within social groups are abandoned, reinforced, or changed over time by the collective behaviors of individual actors (Dolbec \& Fischer, 2015; Powell \& Colyvas, 2008). For example, Scaraboto and Fischer (2013) apply institutional change theory to chronicle how plus-sized women, as a collective identity, urged the fashion marketplace to be more inclusive.

Such attempts by collectives require not only a large enough group with similar needs, but also change agents, or as elaborated by Scaraboto and Fisher (2013, p. 1237), "institutional entrepreneurs...people or groups who attempt to act on their dissatisfaction in order to change the field." These agents require "symbolic capital" to influence changes in the marketplace, which can make attempting institutional change unsuccessful due to several factors: lack of political support, weak ties with multiple stakeholders, or subversion by the dominant logic (Scaraboto \& Fischer, 2013; Olsen \& Boxembaum, 2009; Rao \& Girogi, 2006). As a result, "institutional logics can both constrain and enable institutional entrepreneurs as they seek to legitimate new practices or delegitimate extant ones" (Scaraboto \& Fischer, 2013, p. 1237). In this study, we investigate how individual tiny house dwellers, who are neither mindless actors, nor larger-than-life "super" change agents, can be both constrained and enabled by the dominant logic of consumption.

\section{Methodology}

Examining such a transition in the cultural context of tiny house dwellers requires an alternative process-driven approach to our investigation. According to Langley (1999), "process theorization" addresses research questions regarding how and why phenomena emerge, develop, and end. Rather than explaining variance, process theorization allows for qualitative investigation of events over time. These events are often "embedded in narratives or stories that help shape their temporal and symbolic contours" (Giesler \& Thompson, 2016, p. 499). Once these narratives have been collected, analytical bracketing is applied via an interpretive lens to understand the data. In this sense, our data collection was analyzed utilizing the lens of institutional change.

Accordingly, this qualitative study utilizes a modified constructivist approach to investigate the transformative process of tiny house dwellers. Our method is based on a paradigm that rejects objective reality and instead recognizes the social construction of the mind in the research process (Guba \& Lincoln, 1989). This perspective has been extensively used in such disciplines as education, psychology, sociology, and nursing where the social interaction between investigator and respondent becomes part of the discovery process. According to Charmaz (2014, p. 14), "the term 'constructivist' ... acknowledges the subjectivity and the researcher's involvement in the construction and interpretation of data."

To implement such an approach, the researcher needs sufficient knowledge and capabilities to understand the activities germane to the field of inquiry while interacting with the subject pool (DiCicco-Bloom \& Crabtree, 2006). This approach is ideal "for semi-structured interviews with respondents by researchers with enough expertise in the field of inquiry to encourage respondents to share and elaborate while leaving interpretation or analysis to an investigative team." (St. Clair et al., 2018, p. 395). The primary researcher for this study built and lived in a tiny house, allowing us to bring a unique level of expertise and perspective to this research. This researcher's experience and expertise gave us an opportunity to capture subtle details in the respondents' experiences and transformational processes to this style of living.

Upon approval by the group administrator, 21 tiny house dwellers were recruited from a popular social media platform. Interviews were conducted over the course of multiple email exchanges where participants were asked an initial set of questions and then contacted again for follow-up questions and/or clarification questions. The interviews took place primarily between 2018 and 2020. As depicted in Table 1, members of this group consisted of some of whom had only recently moved into a tiny house, and others who 
Table 1 Characteristics of participants

\begin{tabular}{|c|c|c|c|c|c|c|}
\hline Name & $\begin{array}{l}\text { House- } \\
\text { hold } \\
\text { Size }\end{array}$ & Time in tiny house & $\begin{array}{l}\text { Age range } \\
\text { (Years) }\end{array}$ & Family description & Geographic location & $\begin{array}{l}\text { Expected duration of } \\
\text { tiny house living }\end{array}$ \\
\hline Amy & 1 & 8 months & $51-60$ & Single, grown children & $\mathrm{n} / \mathrm{a}$ & The rest of my life \\
\hline Ann & 2 & 1 year & $51-60$ & Single with child & Florida, USA & Forever \\
\hline Ben & 2 & 2 months & $21-30$ & Engaged & Arizona, USA & At least five years \\
\hline Brad & 1 & 2 years & $31-40$ & Single, grown children & Nova Scotia, Canada & Until Jesus calls me home \\
\hline Cathy & 1 & Unknown & $51-60$ & Single, grown children & Sydney, Australia & $\begin{array}{l}\text { Till when and if I can build a real house } \\
\text { that is not a shipping container }\end{array}$ \\
\hline Chelsey & 2 & 1 year and 3 months & $21-30$ & Married, no children & $\mathrm{n} / \mathrm{a}$ & One to three more years \\
\hline Clare & 2 & 4 months & $21-30$ & Married, no children & California, USA & At least three years \\
\hline Dan & 1 & About 1 year & $21-30$ & Single & Canada & Another two years at most \\
\hline Debra & 3 & 7 years & $51-60$ & Married with children & $\mathrm{n} / \mathrm{a}$ & I don't ever plan not to \\
\hline Eddie & $\mathrm{n} / \mathrm{a}$ & 4 years & $21-30$ & Single & $\mathrm{n} / \mathrm{a}$ & Not sure \\
\hline Evan & 1 & 5 years & $21-30$ & Single & $\mathrm{n} / \mathrm{a}$ & In some form or another forever! \\
\hline Fiona & 1 & 4 years & Over 60 & Single, grown children & N. Carolina, USA & As long as possible \\
\hline Gabi & 1 & 6 months & $51-60$ & Single & Illinois, USA & $\begin{array}{l}\text { As long as it meets my needs and pro- } \\
\text { vides me the life I want to live }\end{array}$ \\
\hline Helen & 2 & 3 years and 3 months & Over 60 & Married, grown children & $\mathrm{n} / \mathrm{a}$ & For the rest of my life \\
\hline Jade & 1 & 6.5 years & Over 60 & Single, grown children & California, USA & Another two years \\
\hline Kelvin & $\mathrm{n} / \mathrm{a}$ & 7 years & $21-30$ & Married & $\mathrm{n} / \mathrm{a}$ & 10 years \\
\hline Linda & 2 & 18 months & $31-40$ & Married & $\mathrm{n} / \mathrm{a}$ & $5-6$ years \\
\hline Lucy & 2 & Unknown & $21-30$ & Married & Colorado, USA & At least for a few years \\
\hline Macy & 2 & 6.5 years & $31-40$ & Married & Texas, USA & Around $5-10$ years \\
\hline Ned & 2 & 4 years & $31-40$ & Married & Mississippi, USA & Indefinitely. Even if we move out, we'll \\
\hline Nora & 2 & 4 years & $31-40$ & Married & Mississippi, USA & $\begin{array}{l}\text { never get rid of it, and we'll use it in } \\
\text { some capacity }\end{array}$ \\
\hline
\end{tabular}

All participants have been given pseudonyms to protect their anonymity

had lived in a tiny house for several years. These participants collectively possessed over 50 years of experience in transitioning to living in tiny houses. Our participants came from a variety of family situations (single, married with children, or retired), age demographics (early $20 \mathrm{~s}$ to senior citizens), and varied in the length of time intended to stay in a tiny house (some planned to stay only a few years, while others saw it as a permanent housing solution). Our participants primarily lived in the United States, but some also lived in Australia and Canada.

\section{Analysis Procedures}

To analyze our qualitative data, we used a hybrid approach referred to as systematic combining of emergent themes guided by theory (Dubois \& Gadde, 2002; Wagner et al., 2010). Here, many qualitative researchers have noted that no indicative research can be conducted without some underlying theory or model as a guiding framework (e.g., Deshpandé, 1983; Eisenhardt, 1989; Fetterman, 2019; O’Donnell \& Cummins, 1999). Using existing literature in this way provides an additional level of trustworthiness, because it represents a vast body of data against which inductive researchers may triangulate both the theoretical consistency and novelty of their findings (Glaser, 1998).

To code the data, we used a qualitative coding software, QDA Miner v 4.1. In the first stage, the research team coded the participant responses, line-by-line. The entire body of text we analyzed included 24,401 words (i.e., about 72 pages of double spaced text). The research team met regularly to discuss various instances of specific codes, resolve any areas of disagreement or ambiguity, and consolidate redundant or very similar codes. Next, the research team used an axial coding process wherein several "core" coding categories began to emerge (e.g., Corbin \& Strauss, 2014). Here, the research team iterated back and forth in a constant comparison process to determine which of the granular codes fit into each core category and which of the open codes were most theoretically relevant. Thus, we provide a novel contribution to institutional theory literature and answer the call for more in-depth focus on the change process of individual actors during institutional change (Powell \& Colyvas, 2008; Scaraboto \& Fischer, 2013). 


\section{Findings}

Our findings revealed that tiny house dwellers face three major logic conflicts that impact and challenge day-to-day living practices. Each of these conflicts involved cognitive, normative, and regulative change processes that acted synergistically in an attempt to legitimize an alternative lifestyle that challenges the status quo of consumption as an institution: Social Community - changes in how these individuals associated with other people in their personal and social lives; Civic Engagement - changes in how these individuals dealt with formal authorities, sanctioning bodies, and civic oversight groups in transitioning to tiny house living; and Marketplace Interactions - changes in the symbolic meaning and importance of existing, acquired, and consumption of possessions and experiences.

\section{Social Community}

There emerged several implicitly understood social practices surrounding tiny houses, including ones that were quite awkward that took cognitive effort to learn and, ultimately, redefine the meaning of everyday objects and routines. For example, learning how to use a composting toilet (owners and guests alike), adjusting to the new norm of entertaining guests by moving outside to patios, firepits and common areas all had the potential to make guests uncomfortable (Mitchell, 2017). These social norms and expected behaviors represented a shift from the logic of mainstream living options and were the source of much the social shifts that took place in the lives of these tiny house families and individuals. Here, tiny house dwellers not only had to adjust to new ways of interacting with others, but also educate others about the new cognitive categories of meaning associated with tiny living spaces.

Several tiny house dwellers in our study described others' reactions to their extreme choices as negative. From feeling ostracized by friends and family for their "strange" choices, to the awkwardness of having other people in their private, small spaces, the participants felt challenged in adjusting to redefined social community norms. On the other hand, some felt quite positive about their changing social situations. According to these respondents, their new style of living invoked curiosity, kinship, and new normative, regulative, and cognitive routines for the better. In analyzing their experiences, two main practices (see Table 2) emerged related to social community institutional transitions: social function and social interdependence.

\section{Social Function}

There were both positive and negative consequences for these individuals as they clashed with social convention in the process of adapting to tiny house living. This experience resulted in several possible reactions, including disengaging from social activities, modifying existing social activities to be more compatible with tiny house living, and cognitively learning to create entirely new social routines.

\section{Disengagement}

Many of the participants expressed feeling like an outcast in society because of their choices, sometimes even among their close friends and family members. This sentiment was one of the most common remarks in our analysis - the feeling of being rejected by many norms of mainstream society. Debra (seven years) ${ }^{1}$ noted other people's opinions as one of the main challenges to overcome in making the decision to live a tiny home:

Other people's opinions [are a challenge]. Everyone has one, most aren't very kind when it comes to living tiny.

Jade (six and a half years) experienced social rejection on multiple fronts - from friends, neighbors, as well as facing regulative opposition from social actors in funding and building her house, leaving her feeling socially isolated:

Almost every builder, banker, fundraiser, friend, and neighbor I spoke with thought I was crazy...

Others mentioned similar experiences recalling how "friends didn't 'get it,' and still don't" (Fiona, four years), or that they had experienced "psychological issues associated with choosing an alternative lifestyle, other people thinking you're crazy" (Dan, one year). This feeling of being socially stigmatized resulted in a pattern of reactions that ranged from finding new or adapted social patterns to fit their new lifestyle, or in more extreme cases, withdrawing from social interactions altogether. In this context tiny house dwellers experienced the convergence of tensions from both the normative and regulative institutional transitions taking place.

Other interviewees, however, came to permanently reject certain aspects of social norms in the lifestyle they were transitioning away from. The tiny living spaces themselves often constrained the extent to which people could participate in social rituals, such as inviting guests into one's home. Chelsey (15 months) talked about not being able to "really have company at our house now." Amy (eight months) related how she no longer had guests over, in part because extremely limited square footage meant she could not have a "big table for gathering." Because tiny house

\footnotetext{
1 To add additional context for each quote we include (in parentheses) the length of time each participant had lived in a tiny house at the time these interviews were conducted.
} 


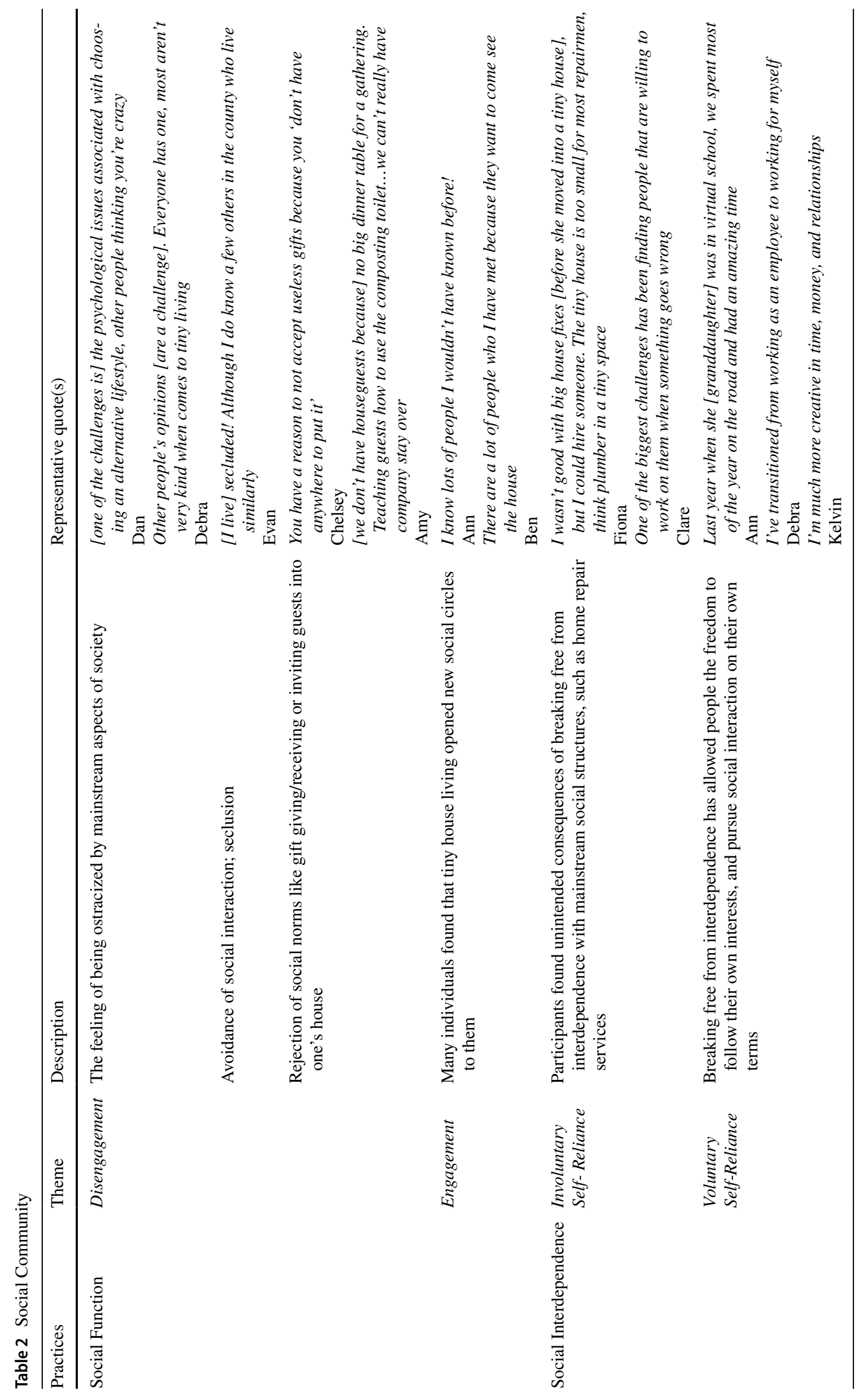


living presented some unique challenges related to privacy and social decorum, or as she put it, "teaching guests how to use the composting toilet" awkward situations such as this made her shy away from the social norm of hospitality. Composting toilets are common in tiny houses due to the inability of some dwellers to link up to a municipal wastewater system. They are essentially "dry" toilets where users must add sawdust or coconut fibers over their waste until it decomposes naturally. These toilets often leave a lingering odor and can be quite uncomfortable for guests who are not used to them, making it a significant social barrier for tiny homeowners who wish to host friends and family in their homes. Even for those who have a more advanced plumbing system, they still often deal with septic systems and sewage tanks on their tiny houses that need to be periodically emptied. As Ned (four years) noted:

We talked about having a composting toilet, but were able to find an alternative because my wife basically told me that I would be exclusively in charge of cleaning and maintenance if we went that route.

Although there were a variety of social norms that tiny house dwellers confronted, some subtle, and others not, this plumbing situation was perhaps one of the most salient, as it was mentioned by eight of our participants as a challenging aspect of living in a tiny house. Further, many online forums or online advice articles dedicated to tiny houses devote significant time and space regarding how to handle composting toilets, which represents a significant cognitive learning curve in itself, a new type of normative social interaction, and a new regulative dilemma in terms of sewage policies.

\section{Engagement}

Despite many of our participants feeling rejected by mainstream society, they still felt a need for meaningful social connection in a way that was not denigrating to their transitions toward tiny house living. For some, they sought new social interactions in a like-minded community that was more understanding and reinforcing of their values. These individuals were intentional in reconstructing normative social ties that were more in line with their attitudes toward tiny houses. Ann (one year) talked about how the social aspect of the tiny house community, and not just the act of transitioning to a smaller living space, had changed her life for the better by introducing her to "lots of people I wouldn't have known before..." and widening her social circle rather than constricting it. Ann also described the process of becoming initiated into the tiny house community. Like several of the participants we interviewed, she went to a weekend workshop for tiny house living. After this initial foray into the mental categories and cognitive shifts required to transform to such a lifestyle, she continued to meet others who were on the same path. The tiny house community opened up new community norms and social opportunities, as many of these houses are custom built, and attract attention from others who either already lived in tiny houses or who were interested in learning about making the transition to a tiny house. Ben (two months) explains,

There are a lot of people who I have met because they wanted to come see the house.

\section{Social Interdependence}

The second common practice identified within the social community domain was the degree to which these tiny house dwellers relied on themselves or others. This choice often was the natural outcome of feeling socially isolated, but some of these individuals pursued isolation more than others in the face of social difficulties. These choices were sometimes voluntary, but often were driven by necessity, and impacted the way tiny house dwellers engaged in social rule following, adopted social roles, and incorporated social routines into their daily lives. Some of the transitions these individuals made also resulted from the real (or perceived) ostracization they felt from their previous social circles about moving into a tiny house.

\section{Involuntary Self-Reliance}

One frequent reason for self-reliance that emerged was foregoing the hiring of traditional service providers who simply did not have the cognitive expertise or interest in providing home maintenance services on such a small scale (despite the fact that nearly all these houses had fully functional roofs, electrical arrays, and plumbing systems that needed ongoing maintenance). Fiona (four years) talked about transitioning to relying on herself for home repair and maintenance:

...I wasn't good with big house fixes [before she moved into a tiny house], but I could hire someone. The tiny house is too small for most repairmen, think plumber in tiny space...

Similarly, Clare (four months) remarked:

...one of the biggest challenges has been finding people that are willing to work on them when something goes wrong...

\section{Voluntary Self-Reliance}

In the two previous cases, these women subsequently developed a sense of self-reliance because of being excluded from specific socially normative enterprises (e.g., traditional home repair services) due to their decision to live in tiny 
houses. Others, however, voluntarily adopted a greater selfreliance because they felt it afforded them the freedom to engage in the lifestyle they desired. One of the participants talked about homeschooling her grandchild, foregoing the social norms and regulations surrounding public and private schools which are centered in a specific physical location and rely on others (e.g., teachers, administrators, etc.). Ann (one year), whose house was on wheels and able to be towed, talked about this type of homeschooling self-reliance as a largely positive aspect of tiny house living:

Last year when she [granddaughter] was in virtual school, we spent most of the year on the road and had an amazing time.

As a result of living in tiny houses, our participants transformed their social functions when interacting with others. At the same time, they also learned to be more independent and self-reliant, resulting in a cognitive shift in what it means to live minimally in the tiny home context. These findings suggest that tiny house dwellers as a collective identity face the same logic conflicts in social settings (Neilsen \& Lockwood, 2018).

\section{Civic Engagement}

The tiny house dwellers we interviewed also found themselves in conflict with the logic of municipalities and civic governing bodies. Although some laws vary greatly from jurisdiction to jurisdiction, there appeared to be a surprising degree of uniformity, and a form of mimetic isomorphism (DiMaggio \& Powell, 1983) in effect with regards to public policy and laws surrounding tiny house living. Our participants expressed concerns about legal issues that centered around zoning laws. This resulted in several of our participants reassessing the cognitive and regulative logic of what it meant to be a law-abiding citizen and how they interacted with municipal bodies. Two practices emerged as we examined the facets of this institution within the tiny house community (see Table 3): awareness of sanctions and adaptation to sanctions.

\section{Awareness of Sanctions}

The tiny house dwellers interviewed felt the weight of government intervention and sometimes formal sanctions that were, at best, not designed to accommodate them, and, at worst, actively working to deter them because of their lifestyle choice. Here, the cognitive meaning of a dwelling, the expected norms of being a resident in a neighborhood, and the questionable legality of such a living situation came into play. Particularly among those individuals who had spent a year or less living in their tiny house, this proved to be a discouraging and unexpected aspect of their transition.

\section{Discouragement}

Several respondents reiterated that government regulations did not make sense to their situation, especially when they felt they were trying to be a positive contributor to their community, rather than a drain on public resources, the environment, or social welfare. These clashes with regulative institutions were a source of discouragement, and in some cases, actively worked against these individuals' lifestyle transitions, both cognitive (i.e., making them feel uncertain about their new dwelling choice) and normative (i.e., feeling in opposition to community). Perhaps the bleakest example came in a comment from Dan (one year), who spoke with a sense of helplessness about his inability to continue in the tiny house lifestyle because of government intervention. Dan, like several others we interviewed discovered after he moved into his tiny house that he was in violation of local zoning laws, resulting in being told that he had to move out of his tiny house, or move his tiny house outside city limits:

...My house is a benefit to me, to others in the community (money to landowners [for parking fees], [sales] taxes I pay by not moving elsewhere, and not a drain on others...I've currently been given six months to leave my home city with my tiny house. It feels terrible to be punished for making necessary, wise financial decisions and solving my own problems of how to live well and get better. I would change the problems local government create around tiny houses.

\section{Hopefulness}

Others expressed similar frustrations, yet seemed to understand some of these issues before moving into a tiny house. This indicated a hopefulness that things could change for the better if they stayed the course. Gabi (six months) remarked:

Given all the issues with parking and zoning, but after it all, it was not a big enough deterrent for me not to take the plunge.

Clare (four months) also acknowledged government resistance but seemed undeterred, even hopeful, in her language:

With the zoning issues in so many places, there are some significant barriers that are yet to be overcome to make it more accessible and more mainstream.

\section{Adaptation to Sanctions}

Often put in untenable positions of having to abandon their lifestyle choices, tiny house dwellers found ways to adapt, rather than move back into traditional housing. These participants engaged in at least two different coping mechanisms 


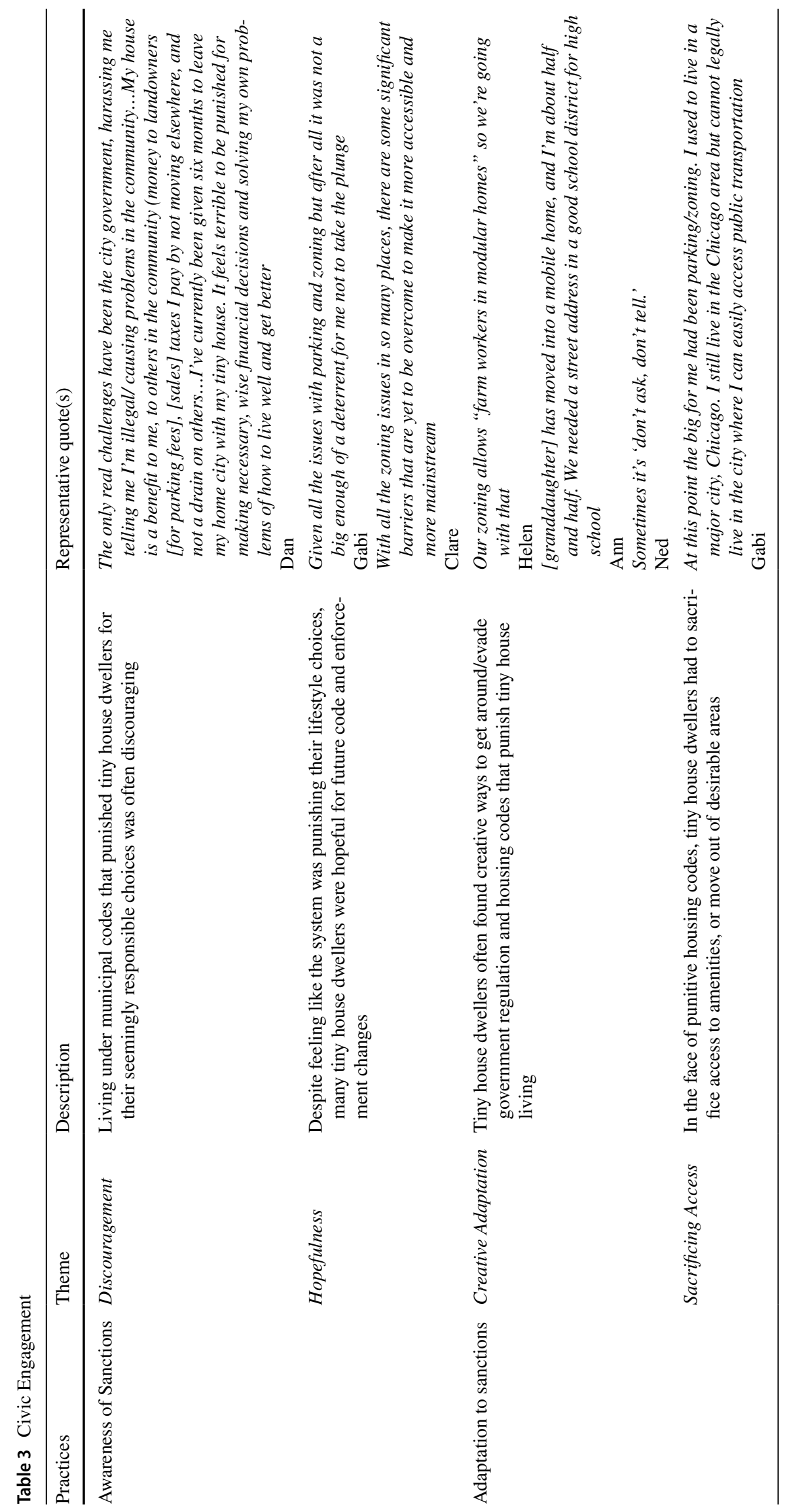


in the face of government sanctions - creative adaptation and sacrificing access. In a sense, the regulative institutions they came in conflict with actually solidified their sense of identity and what it meant to be part of the tiny home community, both from a cognitive and normative perspective.

\section{Creative Adaptation}

Once these individuals became cognitively aware of obstacles to their lifestyle posed by local ordinances, many of them sought to find creative ways to make their tiny houses viable, even in the face of opposition from local municipalities. Helen (three months full-time, three years part-time), relied on a creative interpretation of existing laws to work around government regulations and remain in her tiny house while avoiding harassment by local authorities:

Our zoning allows farm workers in modular houses so we're going with that.

Ned and Nora (four years) also talked about their strategy for avoiding compliance with the law regarding local ordinances surrounding tiny houses by simply not drawing attention to themselves:

Sometimes it's don't ask, don't tell...

Ann (one year) modified her living arrangements by moving her granddaughter to a mobile home while she primarily resides in a tiny house to have a physical address in a desirable school district:

... she [granddaughter] has moved into a mobile home, and I' $m$ about half and half. We needed a street address in a good school district for high school.

\section{Sacrificing Access}

Gabi (six months), on the other hand, adapted to what she perceived as government interference by simply moving to a new jurisdiction. However, as she notes, this required her to make undesirable tradeoffs in the form of losing access to public transportation:

At this point the big [issue] for me had been parking/ zoning. I used to live in a major city, Chicago. I still live in the Chicago area, but cannot legally live in the city where I can easily access public transportation.

Our findings related to civic engagement are a first glimpse into the potential of tiny house dwellers, as a collective identity with new social norms, to be able to change the logic of zoning laws and public policy. The insights collected here also reveal the passion and determination of this group to continue such a lifestyle despite its conflict with social and regulative norms. Given the quotes discussed above, these individuals face ethical and legal dilemmas as they are in direct conflict with regulatory institutions.

\section{Marketplace Interactions}

In addition to social community and civic engagement, tiny house dwellers experienced shifts in how they interacted with the logic of the marketplace as an institution. How they valued current possessions and what every day purchasing activities meant to them emerged as key challenges. The main practices (see Table 4) that emerged were the changing symbolic value of possessions, object quality preferences, and meaningful consumption experiences.

\section{Symbolic Value of Possessions}

The most obvious manifestation involved the symbolism inherent in individuals' personal purchasing habits and the symbolic value of their possessions, representing a shift in the cognitive institution of consumption. As past scholars have noted, individuals are increasingly taking stock of the ways in which their work creates inputs for consumption and, ultimately, choosing to consume differently, according to their values and ethical aspirations (O'Sullivan \& Kraisornsuthasinee, 2019). Those changes, however, necessarily entail shifts in the symbolic value that possessions hold, and these shifts emerged among our tiny house dwellers in several ways which we discuss below.

\section{Ownership as Bondage}

One of the transitions in terms of possessions was the way tiny house dwellers perceived the objects they owned, and the individual meaning ascribed to the acts of purchasing and ownership. While making the transition to tiny houses, there was somewhat of a paradox these individuals experienced. What many outsiders would view as restrictive consumption came to signify freedom, and they came to see their old possessions as burdens, a significant cognitive shift in how they viewed, consumed and valued possessions. Such behaviors are similar to research findings in the literature on voluntary simplicity (e.g., McDonald et al., 2006).

While some recent work in sociology has examined material affinities, particularly as objects tie individuals to their familial and social networks (e.g., Holmes, 2019), many of these tiny house dwellers intentionally severed ties to objects with which they felt affinity. Interviewees often viewed these painful sacrifices of meaningful objects as part of the process of liberating themselves from the burden of possession. In doing so, they also contributed to the normative shift in their social circles as objects were left behind and new 


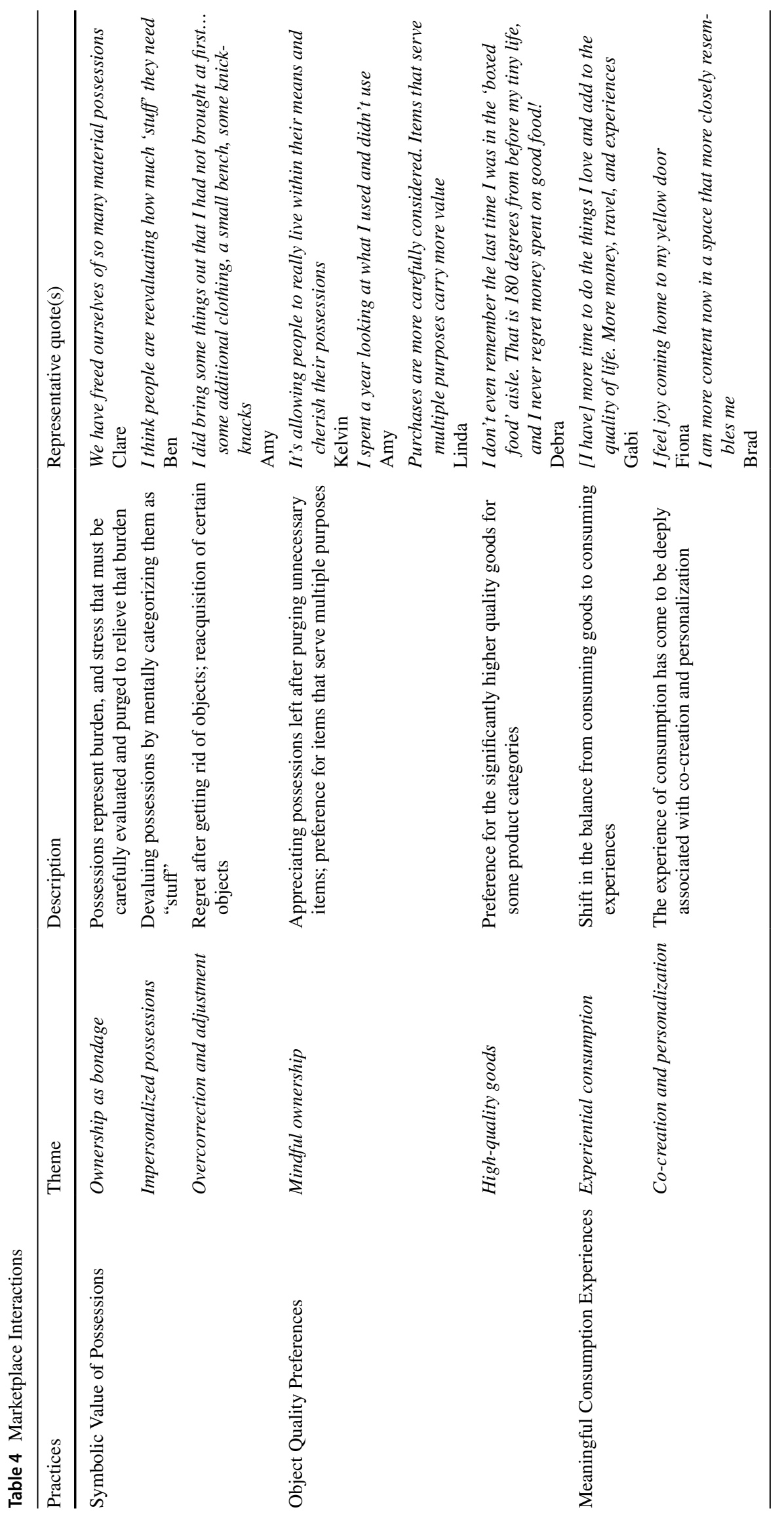


friends, social circles, and social communities took their place.

In their process of transition, tiny house dwellers were also more cognizant of the items they bought, so their sense of freedom came only when they voluntarily accepted the constraint of extremely restrictive purchasing. Indeed, even the tiny houses themselves served as a very tangible structural boundary to curb their impulse to purchase non-necessities. By intentionally subjecting themselves to restrictive spaces, these tiny house dwellers created a situation wherein purchasing more than they needed cognitively became an inconvenient and frustrating problem rather than a hedonically satisfying act. In doing so, they furthered their pursuit of responsible consumption and were able to break free of some of the purchasing habits in their old lifestyles.

By engaging in such an extreme act of simplification, possessions were no longer a source of stress and consternation, but instead became symbolic of freedom. Some, like Clare (four months), used words such as "freed," to describe their lives after getting rid of what was, for many of them, nearly all of what they owned:

We have freed ourselves of so many material possessions...

Ann (one year) talked about the positive difference tiny house living made in their worry about their material possessions during hurricane season:

This past storm season when we were hit by Irma was actually the least stressed I've even been about my 'stuff.'

\section{Impersonalized Possessions}

As illustrated by Ann's quote above, one of the subtle ways the meaning of ownership changed was evident in the way these individuals labeled their old possessions as "stuff." This language of deemphasizing material possessions seemed to align well with their belief that only a precious few possessions were worth keeping, and everything else was just superfluous. As these individuals began to selfimpose restrictive consumption and ownership, the objects that did not fit into that process were de-emphasized and de-personalized.

Ben (two months) stated:

I think people are reevaluating how much 'stuff' they need.

Gabi (six months) echoed a similar sentiment:

I wanted to live a simpler life, less stuff.

Debra (seven years), talked about the benefits she gained by tiny house living:
Buying less stuff. Having less stuff.

Helen (three months part-time, three years full-time) even labeled anything as "stuff" that she could not accommodate in the limited square footage of her house:

I don't have the refrigerator space for multiples of stuff.

\section{Overcorrection and Adjustment}

Despite the cognitive depersonalization and deemphasizing of objects by labeling possessions 'stuff,' there were also several instances of individuals who over-adjusted in the purging of their possessions and found themselves reevaluating which objects were meaningful to them and which were not. It often took time to construct significance and meaning around the "right" objects, while discarding others that no longer supported the lifestyle they were pursuing. Ben (two months) mentioned buying back something he originally had got rid of in his zeal to purge, although his repurchase was more customized to his living space. In this process, he discovered that some objects carried more significance to him than he originally anticipated:

At first, I didn't think we would have a coffee table, so I sold ours before moving in. I have purchased a new, slightly smaller one to take its place after just a few days of living in the house.

Amy (eight months) talked about holding a few things back, presumably in storage, that she later decided were important to her:

I did bring some things out that I had not brought at first...some additional clothing, a small bench, some knick knacks.

These comments illustrate how, as tiny house dwellers made these cognitive shifts, they experienced over-correction and re-correction in their attempt to interpret meaning through the objects they owned, and even re-negotiated which objects were meaningful to them.

\section{Object Quality Preferences}

Another cognitive transition these individuals experienced, was not simply reducing their volume of purchasing, but developing a new symbolic meaning for what objects meant to them and what kinds of goods they preferred to consume. This translated into a being more conscious of one's possessions, a shift in preference toward valuing multi-purpose items, and a preference for high-price, high-quality goods in certain product categories. 


\section{Mindful Ownership}

After making dramatic changes to the quantity and type of possessions they owned, tiny house dwellers often had a sense of contentment with the possessions that they retained, and those objects held a greater significance. Kelvin (seven years) used the word "cherish," when he talked about having a greater appreciation of his remaining possessions after making the radical change to voluntarily simplistic living:

It's [tiny houses] allowing people to really live within their means and cherish their possessions.

Nearly all our interview participants discussed the purging they went through in some form or another, and the mindful processes they use when making purchases and deciding what to keep and get rid of. This presented somewhat of a paradox (i.e., people moving away from their past consumption practices and possessions and spending more time thinking about consumption and possessions), but for most, this change seemed largely positive.

Amy (eight months):

I spent a year looking at what I used and didn't use, both as to "stuff" and as to geography in my traditional home.

\section{Evan (five years):}

I am forced to think more seriously before buying anything about whether I need it, where I can put it, and what I'll need to get rid of to make space for it. It's a good thing to be aware of. I also am more aware of my inputs and outputs, including heat and food, trash, water, humanure, and power.

Brad (two years) talked about both the purging process and how his subsequent purchasing behaviors have changed since moving to a tiny house:

Having to decide what to keep and what to donate due to space constraints [was a challenge] but actually it is nice not to have a lot of stuff hanging around...I am more careful about how I spend money... if I don't need it/can't find a space for it, I don't buy it.

This mindfulness played out in several other interesting ways. First, many of our participants talked about shifting from a long-term consumption (e.g., purchasing what I will need today and the foreseeable future) mindset to a shortterm consumption mindset (e.g., purchasing only what I need for today). This was particularly true for food, which, relative to furniture or appliances takes up relatively little space in a house. The institutional transition surrounding food seemed to be that storing up for future use was no longer as important has having adequate space for other objects these individuals valued.
Linda (18 months):

We purchase one small jar of peanut butter at a time instead of two large jars...

Chelsey (15 months):

I used to buy groceries in bulk, but now I don't have as much room to keep multiples of the same item...

Fiona (four years):

I can't store a ton, so no shopping at BJs [wholesale warehouse grocery store].

As these individuals went through the transition process, they were also cognizant of the function of their possessions, preferring to own multi-purpose items. Linda (18 months), echoed a common preference toward objects that served more than one purpose, helping to ease space constraints in tiny houses:

Purchases are more carefully considered. Items that serve multiple purposes carry more value.

Chelsey (15 months), used her move to tiny house living as a normative license to reject gifts from others, because, to her, these objects only served as obstacles in her pursuit of a simpler life:

You have a reason to not accept useless gifts because you 'don't have anywhere to put it.'

In rejecting gifts, not only was she redefining the meaning of a gift for herself, but she was also imposing that newfound understanding on others and fundamentally redefining social interaction with others.

\section{High-Quality Goods}

In some product categories, such as food, these tiny house dwellers made the transition to buying and consuming premium goods, as their financial situations gave them the flexibility to spend money on high-quality products. Debra (seven years) described spending more on premium food items, while also avoiding the regret of buying things she ultimately did not need or was not able to fully appreciate:

I scratch cook all of our food (something I never had time to do before). I buy mostly fresh produce and raw ingredients; I don't even remember the last time I was on the 'boxed food aisle. That is 180 degrees from before my tiny life! And, I never regret money spent on good food!

Dan (less than a year) also commented on spending more, not less, money on certain items: 
I'm financially stable, able to afford the best food and supplements.

As these individuals eliminated or reduced consumption in some categories (e.g., housing, routine purchases, buying groceries in bulk, etc.), the resultant time and financial resources allowed them the ability to spend more money on other product categories that had become particularly important to them.

\section{Meaningful Consumption Experiences}

A final institutional theme that emerged was a change in the meaning of individual consumption, including a shift from consuming goods to consuming experiences. This included a greater emphasis placed on co-creation and personalization.

\section{Experiential Consumption}

Several of the tiny house dwellers mentioned how they were focused on consuming experiences because their tiny houses allowed them to stay mobile. This transition freed up resources to consume differently than they had in the past.

Gabi (six months):

[I have] more time to do the things I love and add to the quality of life. More money, travel, and experiences.

\section{Ben (two months):}

We live minimally anyway and value experiences most.

\section{Co-creation and Personalization}

Finally, many of these individuals found a great deal of meaning in the act of designing and building their own spaces, placing a greater emphasis on quality as co-creators of their own living/domicile experiences. This was another manifestation of the desire to consume experiences over physical goods, although, ironically, it directly involved tangible ownership (i.e., a physical space).

Ben (two months):

I was able to design the entire house. I made a plan and used an app to do a $3 \mathrm{~d}$ mockup. I then worked with an architect to make it possible.

Fiona (four years):

I feel joy coming home to my yellow door.

Brad (two years):

I am more content now in a space that more closely resembles me.
As these quotes illustrate, having spaces that aligned with their personal identity and designed to meet their custom needs was of paramount importance. Even as these tiny house dwellers were purging possessions in other ownership categories, the act of co-creation itself became an experience to be consumed in place of the things they consumed before.

In sum, the logic of marketplace interactions was challenged by tiny house dwellers as their recalibrated behavior toward existing and new possessions is in conflict with the logic of the consumption status quo. These individuals had to adjust and simplify their current possessions, make adjustments in terms of quality versus quantity, and refocus on consumption experiences rather than products.

\section{Institutional Change Processes and Sustainable Transformation}

Through their lived experiences thus far, tiny house dwellers transitioned and challenged the institution of consumption in three ways: social community, civic engagement, and marketplace interactions. As Fig. 1 depicts, we show the significant ways in which these institutions intersect as tiny house dwellers experience the normative, cognitive, and regulative change process. As such, whether consciously or not, they have acted as a collective identity, in an effort to legitimize an alternative way of life. Legitimacy is a central concept in institutional theory (e.g., Scott, 1995) and, if achieved, such symbolic capital of this consumer segment can influence organizations and regulatory agencies to alter the status quo (Scaraboto \& Fischer, 2013).

\section{Sustainable Transformation}

As the center of Fig. 1 depicts, sustainable transformation is where our participants were most passionate about their change process. Despite all the challenges, most of these tiny house dwellers were proud to have made the choice to "live deliberately" by changing commonly accepted normative, regulative, and cognitive practices in pursuit of a new institution of sustainable consumption. They mentioned that this new way of life is a paradigm shift or a complete lifestyle transformation:

...for some it is a fad, for some it's a niche, for me and others, it is a paradigm shift (Amy, eight months).

my life has completely changed in all regards (Eddie, four years).

Our participants also felt a sense of responsibility and accomplishment. They challenged the status quo of consumption by downsizing, making new friends, developing new social communities and mores, and adapting to 
Fig. 1 Instiutional change processes and sustainable transformation

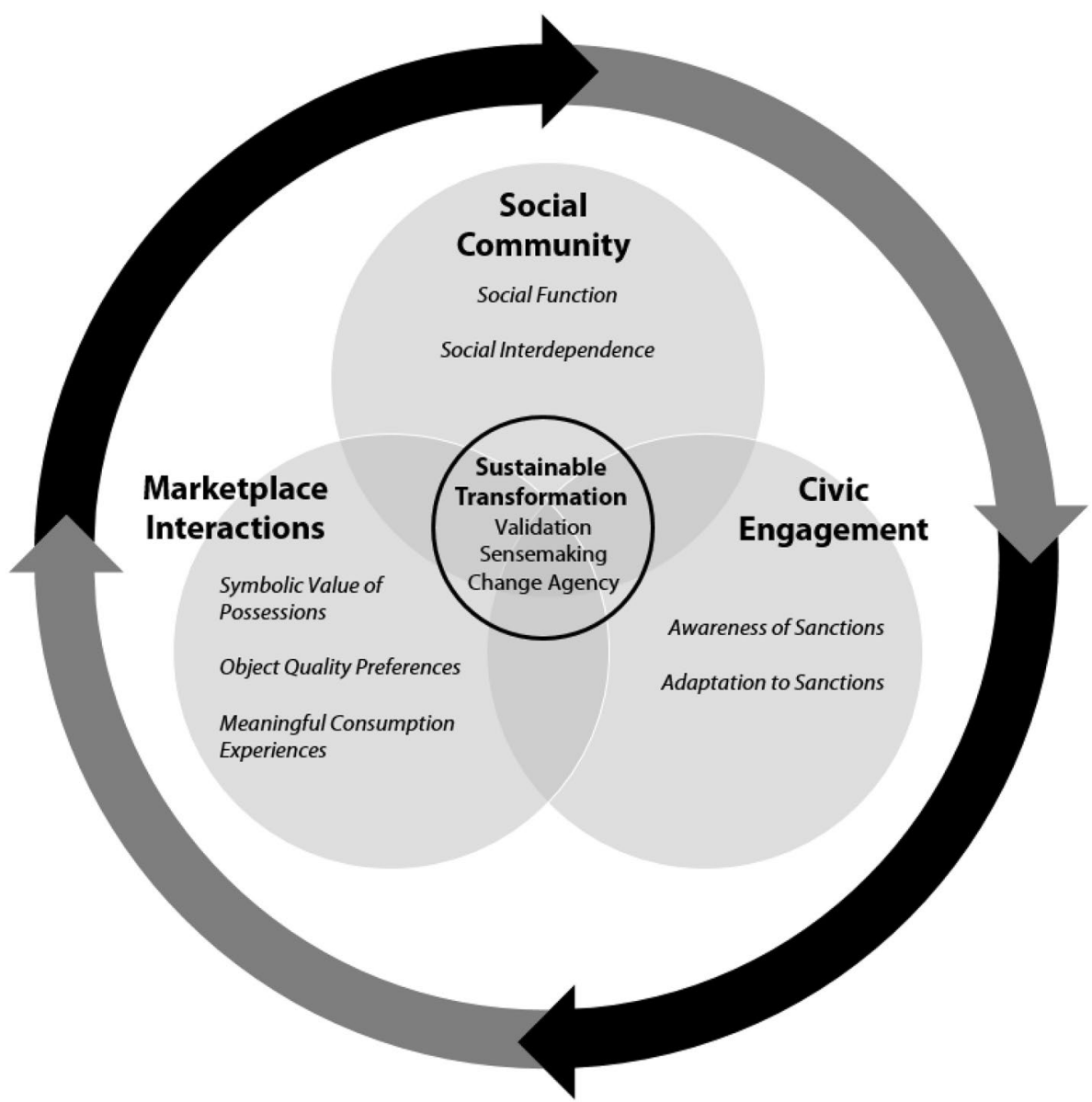

governmental hurdles. Although they were ostracized by those close to them, sometimes harassed by local governments, and had to forego meaningful material possessions, most of our tiny house dwellers felt that it was worth the sacrifice. Making more responsible consumption choices made them feel empowered to lay the groundwork for the next iteration of alternative living, reiterating the concept posed by Scaraboto and Fisher (2013) of institutional entrepreneurship. We discuss next how this sustainable enterprise movement manifests itself in terms of validation, sensemaking, and change agency.

\section{Validation}

Tiny house living as a social movement seems to have preceded the logic of public policy and the willingness of municipalities to accept it as a valid form of housing rather than something to be regulated and/or sanctioned. Tiny house dwellers are constrained by the logic of home ownership and want to enable a new dwelling lifestyle as a social community. For individuals, this means that establishing new social norms not only lays the groundwork for participating in new and/or adapted social rules, rituals, and marketplace routines, but also serves to motivate them collectively to seek validation as an alternative form of housing in an existing system.

Seeking validation prompted some tiny house dwellers to engage in activism, but for others, it also resulted in a redefining of one's social identity (i.e., a normative shift) in order to find acceptance, even if it existed outside of the mainstream social circles they had once been a part of. Macy noted that she "found a stronger connection with our neighbors living in an RV community versus a neighborhood of houses". She ultimately went to work as a sales rep for the company from which she bought her tiny house ("I now am a dealer for Platinum Cottages...we had so many folks stop by our property when we set up 3 park model RV's it inspired me to sell them"). Macy's social circles, including in her professional life, consist almost entirely of individuals within the tiny house community. In her case, her sense of validation comes from the fact that she has simply redefined her social interactions at home and work to only include people who accept and understand her life choices.

This notion of validation also emerged around the need for self-reliance, a type of self-validation in the absence of validation from others whether it be skirting regulations, severing friendships, or learning how to do repairs. Discovering a newfound sense of self-reliance, whether by necessity or 
choice, enabled tiny house dwellers to change their perspective and the meaning imbued in certain social interactions, such as calling a handyman to make a repair or designing and building their homes to their exact specifications.

Additionally, many of our participants could no longer depend on traditional social institutions for help. They often formed new communities of interest to help one another acclimate to tiny house living and acquire the skills necessary to validate becoming more self-reliant. Many of our participants mentioned being first drawn to tiny house living through their encounters with these communities - online, in person, and through television programs. Evan (five years) shared how he was influenced by the tiny house community:

A friend's daughter had been researching blogs about them and shared a few resources. In 2012 there weren't a lot of resources. I attended a [tiny house community] workshop and designed my floor plan there.

This finding parallels collective identity and institutional entrepreneurship as discussed by Scaraboto and Fisher (2013).

\section{Sensemaking}

In the case of tiny house dwellers, the individual choice to move toward such a lifestyle prompted them to make cognitive transitions and interpret their initial experiences differently. Social meaning informs individual meaning, and individuals then participate in social rituals that can convey new symbolism and new meaning back to the group around objects, experiences, and rituals. For example, several of our participants talked about the awkwardness of composting toilets, both because they offered little privacy from other housemates, and because they created uncomfortable social encounters with outsiders invited into their tiny houses. Ultimately, this new reality was accepted and integrated into the logic of what it means to live in a tiny house. Chelsey (15 months) discussed "getting used to" tiny house challenges after only a few months as she began to reinterpret her situation through a new set of perspectives:

Most of the challenges occurred the first few months (being in closer proximity with your significant other more often, climbing a ladder to and out of bed every day, doing laundry more often, having to change the compost toilet, cleaning up dog hair, the dog being in the way [middle of the floor], putting stuff away when you're done because it's easy to make a mess, having less private space), but then you learn to adapt to your new living situation and things become normal and are no longer really "challenges" or at least become less annoying.
Another example of a how individuals interpreted new meaning of 'home' was illustrated by Amy (eight months):

If you do get sad or depressed, there's no other place to go except away. At my 'real' house, I had a yard, an upstairs, and a basement so I could distract myself if I got gloomy.

Amy's comment illustrates how her social reality caused a transition in her construction of meaning, in this case, making sense of the meaning and function of 'home'. Instead of being defined as a place for emotional recharge through solitude, the act of self-soothing through physical distance was no longer a significant association with 'home'. The fact that she is early in this transition is evidenced by still referring to her traditional house as a 'real' house, perhaps indicating that she has completely made the cognitive shift of sensemaking in a tiny house.

\section{Change Agency}

Sustainable transformation to this new way of living also resulted in more collective concern over the status quo and the desire to change it. First, many of these tiny house dwellers were forced out of the traditional neighborhoods they had been a part of to avoid violating zoning laws, and others were deprived access to social services, such as public transportation, because of their living choices. Ned (four years) recalled his experience when constructing his tiny house:

Right after we built our tiny house, our town passed a residential zoning law forcing us out of city limits, and we felt like this was directly targeted toward us, as we were the first family in the area to have a tiny house. Nobody wanted a tiny house in their neighborhood because they felt like having tiny houses in close proximity brought down the value of their houses. There are people all over the country working to try and get zoning laws changed, and we frequently see petitions passed around in the online tiny home community to try and pass favorable regulations and zoning laws.

Because these tiny house dwellers challenged the logic of what it meant to be a typical home owner in a typical neighborhood, they came into conflict with those in close geographical proximity. First, neighbors were not used to such a living concept and made assumptions that, since their homes were much larger and more expensive, a tiny house could undermine the value of their own. It appears that, at a superficial level, society is generally open to tiny houses as a socially responsible and environmentally sustainable housing solution, but less so when tiny house dwellers encroach on individuals' specific social spaces. For example, some 
neighborhoods place a stigma around the presence of tiny homes, associating them with housing solutions of the homeless, for families in dire financial straits, or even as a public safety concern, thus creating social barrier to their full integration and acceptance (Unger, 2017). This creates an interesting social tension that on one hand, allows for the abstract idea of tiny houses as a generally favorable solution to many public challenges, but on the other hand, rejects the way they are concretely manifest in society (e.g., as a next door neighbor). Second, these institutional changes also represented regulative shifts as many of these individuals, some for the first time, actively sought to reform government policy to avoid formal sanctions that resulted from violating established living norms. Thus, tiny house dwellers reflect the notion of institutional entrepreneurship because they are attempting to change and legitimize (e.g., Rao \& Giorgi, 2006) a new concept of living.

By becoming aware of how regulative forces constrain their pursuit of small living and dealing with very concrete regulations and sanctions by local municipalities, the concept of "government" or "municipality" was fundamentally changed and took on a new symbolic meaning. Based on the common sentiment our participants raised about feeling punished by local government, for them, the meaning of these regulative institutions transitioned from not carrying a great deal of symbolism or being an "advocate," to, in the worst case "adversary," an erosion of trust in a public institution. This evolving meaning, in turn, enabled tiny house dwellers to potentially be active change agents in the established institutions under which they lived.

Not surprisingly, some of the strongest sentiments against regulative institutions were from those individuals we interviewed who had spent the most time living in a tiny house. These individuals had likely progressed the furthest through the various institutional transitions associated with tiny house living and had begun to adopt a sense of change agency. Jade (six and a half years) talked about her choices to reject the logic of overconsumption, and the choices of those like her as standing up to formal power structures:

... [tiny house living] frightens many corporations, institutions, and governments that count on masses to be controlled by debt and consumption.

Debra (seven years) takes one step further and represents a potential institutional entrepreneur engaged in activism to change the laws that are problematic for tiny house dwellers:

Tiny houses are solving housing problems. Codes are being formed around them. They will become just another housing option, bit by bit. The legality of parking one, although many of us are working diligently with IRC, local, and state officials for further acceptances of tiny houses as full-time residences.
Such statements support the assertion that individual actors have the potential to collectively transition toward regulative institutional change (Scott, 1995; Scaraboto \& Fisher, 2013; Schlaile et al., 2018).

\section{Discussion and Implications}

Our study explored the normative, regulative, and cognitive transitions individuals made as they transformed their lifestyle into tiny houses. Our qualitative analysis identified several institutional transitions - social community, civic engagement, and marketplace interactions. As social theorists have pointed out, institutional changes are interwoven and reinforce each other to create a new social framework (cf., Scott, 1995; D’Andrade, 1984).

\section{Theoretical Implications}

According to Nielsen and Lockwood (2018), "qualitative transformational solutions refer to qualitative property changes that are fundamentally different than the original components" (p. 46). Transitioning to a tiny house is indeed fundamentally different than traditional living spaces as seen in our analysis. These individuals have come into conflict with the logic of consumption as an institution (Thornton et al., 2012), yet they have adapted and found solutions to such conflict.

Citing stakeholder theory and corporate social responsibility, Sharma and Henriques (2005) argue that businesses should create objectives that consider sustainability. This has been reiterated and advocated by Sheth and colleagues (2011) in their call for organizations and individuals to adopt a paradigm shift toward more responsible consumption. Our study adds to this area of research by examining how individuals participating in a social movement, such as tiny house living, have the potential to become a powerful voice of influence and legitimization. In doing so, we provide more insight on how consumer social responsibility can influence and attempt to change common practices by organizations (Scaraboto \& Fischer, 2013; Schlaile et al., 2018; Vitell, 2015).

Consumer researchers have also called for more investigation of the "conceptualization of the consumer and the context in which such a subject is formed in order to better understand the relationship between consumer subjects and their environments" (Karababa \& Ger, 2011, p. 738). By focusing on how consumers change and develop new institutional practices for tiny house dwelling, our study adds another research context to this theoretical perspective. Further, according to Geisler and Veresui (2014, p. 842), consumer responsibilization is a "process through which 
consumers are reconstructed as free, autonomous, rational, and entrepreneurial subjects who draw on individual market choices to invest in their own human capital, such that the need for top-down intervention into the market is rendered obsolete." Thus, by legitimizing an alternative form of living and recalibrating their consumption patterns, tiny house dwellers have become part of such a bottom-up movement that has created a consumption ethos of "living deliberately" (Thoreau, 1854). These bottom-up efforts, however, often include tension, sacrifice, and conflict, as we have found in our qualitative investigation.

The conflict and tension these consumers often felt also gives insight into some of the micro foundations of institutional theory. Past scholarship in institutional theory has called for a deeper exploration of the role of individual actors in institutional changes. Here we find, at the individual level, that many of these participants were willing disobey regulative expectations, intentionally skirting the law, to legitimize a more sustainable and responsible form of consumption. In some cases, the very institutions designed to create social order were actively working against them because they did not fit into the prevailing paradigm, forcing them to act defiantly.

\section{Managerial and Ethical Implications}

Insights from our research present practical and ethical considerations for marketers. First, we offer insight into the buying preferences of tiny house dwellers who want to participate in a movement toward responsible consumption. This type of consumption does not necessarily result in consumers with little or no buying power. On the contrary, our research showed that many of these tiny house dwellers were willing to pay a premium for specific categories of luxury goods, services, and experiences, albeit with a different mindset than a traditional consumer (e.g., "I never regret money spent on good food," "I'm....able to afford the best food and supplements"). Ignoring this market could be a potential strategic oversight for companies that sell building materials, groceries, travel experiences, as well as a myriad of other industries. In fact, marketers have taken note of this growing segment, as IKEA currently offers tiny house kits, where customers can customize to their specific preferences (Berg, 2021).

Second, marketers may need to reconsider how their products and services create value for customers. As this market segment is seeking ways to transform its consumption choices (Albinsson \& Perera, 2012; Markman, 2020), marketers who focus on product quality may find ways to cocreate products that are tailored to these individuals' needs, and marketers whose products serve multiple purposes may create a competitive advantage. These insights can create opportunities for specific niche markets, such as storage facilities for those tiny house dwellers who wish to store items rather than completely purging them, or opportunities to give items to charity to allow others to reuse and/or recycle them. This research may also point to new market opportunities for service providers (e.g., plumbers, electricians, etc.) willing to invest in the know-how and specialized tools required to service houses with custom engineered "tiny" systems. In these ways, individuals may influence corporations to change their market strategies as the institutional practices of consumption are continually revised and reconstructed.

Finally, marketers may need to refine their product development strategies using an ethical lens if they wish to do business in a socially responsible way. For example, strategies of planned obsolescence (e.g., Bulow, 1986; Guiltinan, 2009) may serve to perpetuate overconsumption. As more and more individuals try to make do with less and demand that firms act in a sustainable manner that benefits society, marketing strategies that encourage overconsumption may ultimately no longer be a competitive advantage. For example, tiny house dwellers were essentially penalized for purchasing more frequently, but in smaller quantities, rather than purchasing in bulk. Marketers could potentially develop pricing and/or incentive structures to accommodate this type of consumer who, in the same period, may consume the exact same amount, but makes purchases more frequently. Likewise, this issue has implications for packaging and directly ties in with the reusable packaging movement, as both consumers and firms strive to be more environmentally responsible. By allowing consumers to utilize the packing size of their choice (e.g., foods that are delivered to supermarkets in bulk, but distributed in varying quantities on a customer-by-customer basis), firms can be both more environmentally responsible while also meeting an important need of this particular market segment.

At the micro-level, our research provides evidence of ethical dilemmas some of these individuals face as they transform their living situation. Some felt pushed toward deviant and/or almost illegal behavior to achieve what, in their mind, was the greatest ethical good (i.e. becoming debt-free, purchasing smaller quantities, environmental friendliness) and what offers them the greatest sense of agency in their personal consumption choices.

At the firm level, we see evidence of managerial decisions that potentially have ethical implications insofar as they drive consumers toward certain kinds of behaviors that are not sustainable (e.g., overconsumption, rampant materialism, accumulation of too many possessions, etc.). Managers should consider how product and brand management decisions, such as packaging, product quantity, and product usefulness lifecycles can help encourage their customers to consume in more responsible, ethical ways. 
Finally, at the societal level, this research has implications for responsible consumption as an institution. The question remains as to what extent are we willing to make concessions to well-established institutions (e.g., zoning laws and social interpretations of the "right" way to live in a domicile) to allow our society to work better (and more ethically) for all. While established institutions offer benefits to society in the form of shared meaning, order, and stability, the unwillingness to change and adapt can contribute to unethical behavior rather than preventing it. In this vein, the most ethical institutions are those that allow for adaptability, rather than those that remain rigid in the face of demonstrated good.

\section{Conclusion and Future Research}

As reiterated by Bahl and colleagues (2016), "millions of contemporary consumers sleepwalk through a fog of impulses, habits, addictions, compulsions, and decision biases....It is indeed challenging to wake consumers up when they are deeply sedated by promises of pleasures and escapes everywhere in the marketplace." (p. 198). Our results demonstrate that a promising segment of consumers are indeed not "sleepwalking" at all. Tiny house dwellers have challenged the status quo of consumption as an institution and revealed that such a transformative process can be an arduous yet rewarding journey. Future research could examine how such a lifestyle can be applied to other living situations and solve public problems. In fact, tiny houses have been used as a solution to larger social issues such as homelessness, the disabled (Chaney, 2017), temporary housing for natural disasters (Reggev, 2017), and a solution for quarantine living (Chang, 2020). Future research could examine how tiny houses can aid in solving public crises.

Our results also reveal that the tiny house movement faces regulatory challenges. Critics and neighbors believe that tiny houses can bring their property values down. Concerns about turning these houses into rental properties (e.g., AirBnB neighborhoods) also abound (Spesard, 2019). Future research could investigate online tiny house forums and social media communities to gauge how public sentiment evolves toward this lifestyle. For those building tiny houses, simple logistics are still a challenge. For example, a newly constructed house must be over a particular minimum square footage to qualify for the local building permits. As our results demonstrate, tiny house dwellers have learned to adapt and even become change agents. Future research could investigate the progress of changing regulations in the public policy realm. A related direction could be how COVID-19, along with concerns of social gatherings and individuals' economic well-being has influenced municipalities' willingness to reconsider non-traditional forms of residence.

Our findings also have several limitations. First, we examine specifically tiny house ownership as a manifestation of the broader phenomenon of responsible consumption. There are many individuals who pursue responsible consumption in other ways, such as minimalism, rejecting the use of credit cards and other forms of debt, communal living, etc., which we do not address in this paper, but could be a fruitful avenue of future research, both qualitatively and quantitatively. Finally, our research is limited to a narrow period in which we interviewed individuals about the transition process of moving to a tiny house, and the permanence of these individuals' choices is largely unknown to us. Following individuals over longer periods of time could yield additional insight into how these transitions occur, and how they impact society at large.

Based on our findings, "living deliberately" can ultimately be rewarding. Rees and Wackernagel (1996, p. 242) stressed the importance of sustainable lifestyles stating, "we in the wealthiest cities must do what we can to create cities that are more ecologically benign (including, perhaps, learning to live more simply, so that others may live at all)". Such a declaration in the context of tiny house living presents an interesting paradox. Many socially responsible organizations and governments would agree in principle that sustainable living is a desirable goal, yet, those same entities obstructed individual efforts to do so. Future research in consumer ethics and public policy should examine how social systems often obstruct themselves in making progress toward commonly held goals when innovative means to do so do not fit neatly into their existing institutional paradigms. This study hopes to be a launching pad for future research in pursuing sustainable living options.

\section{Declarations}

Conflict of interest The authors declare that they have no conflict of interest.

\section{References}

Albinsson, P., \& Perera, B. (2012). Alternative marketplaces in the 21st century: building community through sharing events. Journal of Consumer Behaviour, 11(4), 303-315.

Bahl, S., Milne, G., Ross, S., Mick, D., Grier, S., \& Boesen-Mariani, S. (2016). Mindfulness: Its transformative potential for consumer, societal, and environmental well-being. Journal of Public Policy and Marketing, 35(2), 198-210.

Barrett, B. F., Horne, R., \& Fien, J. (2016). The ethical city: a rationale for an urgent new urban agenda. Sustainability, 8(11), 1197. 
Berg, B. (2021). Need to Get Away? How About an IKEA Tiny House? Architectural Digest. Retrieved June 9, 2021, from https://www. architecturaldigest.com/story/ikea-tiny-house

Bulow, J. (1986). An economic theory of planned obsolescence. The Quarterly Journal of Economics, 101(4), 729-749.

Chadwick, K. (2019). Living Small. Library Journal, 144(8), 31-33.

Chaney, M. (2017). 'Granny Cottages' are a convenient microliving option for seniors. Wric. Retrieved May 19, 2020, from https:// www.wric.com/news/granny-cottages-are-a-convenient-micro-living-option-for-seniors/.

Chang, B. (2020). Tiny home on wheels that was designed to work from home in during the pandemic saw a huge spike in interest in 2020. Business Insider. Retrieved January 16, 2021, from https:// www.businessinsider.com/tiny-home-wheels-designed-coron avirus-work-from-home-2020-11.

Charmaz, K. (2014). Constructing Grounded Theory : A practical guide through qualitative analysis (2nd ed.). Sage.

Corbin, J., \& Strauss, A. (2014). Basics of qualitative research: Techniques and procedures for developing grounded theory. Sage publications.

D'Andrade, R. G. (1984). Cultural meaning systems. In R. A. Shweder $\&$ R. A. Le Vine (Eds.), Culture theory: Essays on mind, self, and emotion. Cambridge, England: Cambridge University Press.

Davies, I., Oates, C. J., Tynan, C., Carrigan, M., Casey, K., Heath, T., \& Wells, V. (2020). Seeking sustainable futures in marketing and consumer research. European Journal of Marketing, 54(11), 2911-2939.

Davis, B., Ozanne, J., \& Hill, R. (2016). The transformative consumer research movement. Journal of Public Policy and Marketing, 35(2), 159-169.

Deshpandé, R. (1983). "Paradigms lost": on theory and method in research in marketing. Journal of Marketing, 47(4), 101-110.

DiCicco-Bloom, B., \& Crabtree, B. F. (2006). The qualitative research interview. Medical Education, 40(4), 314-321.

Diguette, R. (2017). Lessons from the first 'tiny house' evangelist, Henry David Thoreau. Washington Post. Retrieved May 19, 2020, from https://www.washingtonpost.com/lifestyle/home/lessonsfrom-the-first-tiny-house-evangelist-henry-david-thoreau/2017/ 03/13/3dddc69e-02d0-11e7-b1e9-a05d3c21f7cf_story.html.

DiMaggio, P. J., \& Powell, W. W. (1983). The iron cage revisited: institutional isomorphism and collective rationality in organizational fields. American Sociological Review, 48(2), 147-160.

Doherty, A. M., Chen, X., \& Alexander, N. (2014). The franchise relationship in China: agency and institutional theory perspectives. European Journal of Marketing, 48(9/10), 1664-1689.

Dolbec, P., \& Fischer, E. (2015). Refashioning a field? connect consumers and institutional dynamics in markets. Journal of Consumer Research, 41(6), 1447-1468.

Dubois, A., \& Gadde, L. E. (2002). Systematic combining: an abductive approach to case research. Journal of Business Research, 55(7), 553-560.

Eisenhardt, K. M. (1989). Building theories from case study research. Academy of Management Review, 14(4), 532-550.

Elgin, D., \& Mitchell, A. (1977). Voluntary simplicity. Planning Review, 5(6), 13-15.

Etzioni, A. (1998). Voluntary simplicity characterization, select psychological implications, and societal consequences. Journal of Economic Psychology, 19, 619-643.

Fetterman, D. M. (2019). Ethnography: Step by step (Vol. 17). Sage.

Garfinkel, H. (1967). Studies in Ethnomethodology. Englewood Cliffs, NJ: Prentice-Hall.

Giesler, M., \& Thompson, C. J. (2016). Process theorization in cultural consumer research. Journal of Consumer Research, 43(4), 497-508.
Giesler, M., \& Veresiu, E. (2014). Creating the responsible consumer: moralistic governance regimes and consumer subjectivity. Journal of Consumer Research, 41(3), 840-957.

Glaser, B. (1998). Doing Grounded Theory: Issues and Discussions. Sociology Press.

Guba, E. G., \& Lincoln, Y. S. (1989). Fourth generation evaluation. Sage.

Guiltinan, J. (2009). Creative destruction and destructive creations: environmental ethics and planned obsolescence. Journal of Business Ethics, 89(1), 19-28.

Holmes, H. (2019). Material affinities: 'doing' family through the practices of passing on. Sociology, 53(1), 174-191.

Karababa, E., \& Ger, G. (2011). Early modern Ottoman coffeehouse culture and the formation of the consumer subject. Journal of Consumer Research, 37(5), 737-760.

Kaufmann, C. (2015). Tiny houses are becoming a big deal. AARP Livable Communities. Retrieved December 11, 2020, from https://www.aarp.org/livable-communities/housing/info-2015/ tiny-houses-are-becoming-a-big-deal.html.

Kraisornsuthasinee, S., \& Swierczek, F. (2019). Beyond consumption: the promising contribution of voluntary simplicity. Social Responsibility Journal, 14(1), 80-95.

Langley, A. (1999). Strategies for theorizing from process data. Academy of Management Review, 24(4), 691-710.

Lim, W. M. (2017). Inside the sustainable consumption theoretical toolbox: critical concepts for sustainability, consumption, and marketing. Journal of Business Research, 78, 69-80.

Lunde, M. B. (2018). Sustainability in marketing: a systematic review unifying 20 years of theoretical and substantive contributions (1997-2016). AMS Review, 8(3), 85-110.

Mangold, S., \& Zschau, T. (2019). In search of the "good life": the appeal of the tiny house lifestyle in the USA. Social Sciences, $8(26), 1-21$.

Markman, J. (2020). Coronavirus Quarantine Could be Change for Consumer Habits...For Good. Forbes. Retrieved June 1, 2020, from https://www.forbes.com/sites/jonmarkman/2020/03/28/coron avirus-quarantine-could-change-consumer-habits--for-good/\# $288 \mathrm{f} 3 \mathrm{~d} 4 \mathrm{c} 696 \mathrm{c}$.

McDonald, S., Oates, C. J., Young, C. W., \& Hwang, K. (2006). Toward sustainable consumption: researching voluntary simplifiers. Psychology \& Marketing, 23(6), 515-534.

Mitchell R. (2017). How to have guests in a tiny house. The Tiny Life. Retrieved May 19, 2020, from https://thetinylife.com/ how-to-have-guests-in-a-tiny-house.

Nielsen, R. P., \& Lockwood, C. (2018). Varieties of transformational solutions to institutional ethics logic conflicts. Journal of Business Ethics, 149(1), 45-55.

Nielsen, R. P., \& Massa, F. G. (2013). Reintegrating ethics and institutional theories. Journal of Business Ethics, 115(1), 136-147.

O'Donnell, A., \& Cummins, D. (1999). The use of qualitative methods to research networking in SMEs. Qualitative Market Research, 2(2), 82-91.

Olsen, M., \& Boxenbaum, E. (2009). Bottom-of-the-pyramid: organizational barriers to implementation. California Management Review, 51(4), 100-125.

O'Sullivan, P., \& Kraisornsuthasinee, S. (2019). You earn as you live as you value: consumption-work dialectic and its implications for sustainability. Sustainability Accounting, Management and Policy Journal, 11(2), 429-450.

Powell, W. W., \& Colyvas, J. A. (2008). Microfoundations of institutional theory. The Sage handbook of organizational institutionalism, Thousand Oaks, CA: Sage. 
Rao, H., \& Giorgi, S. (2006). Code breaking: How entrepreneurs exploit cultural logics to generate institutional change. Research in Organizational Behavior, 27, 279-314.

Rees, W., \& Wackernagel, M. (1996). Urban ecological footprints: why cities cannot be sustainable - and why they are a key to sustainability. Environmental Impact Assessment Review, 16(4-6), 223-248.

Reggev, K. (2017). How tiny and prefab homes can help people recover after natural disasters. Dewll. Retrieved May 26, 2020, from https://www.dwell.com/article/how-tiny-and-prefab-homes-canhelp-people-recover-after-natural-disasters-1e77e19a.

Scaraboto, D., \& Fischer, E. (2013). Frustrated fatshionistas: an institutional theory perspective on consumer quests for greater choice in mainstream markets. Journal of Consumer Research, 39(6), $1234-1257$.

Schlaile, M. P., Klein, K., \& Bock, W. (2018). From bounded morality to consumer social responsibility: a transdisciplinary approach to socially responsible consumption and its obstacles. Journal of Business Ethics, 149(3), 561-588.

Schor, J. (1998). The Overspent American. Multinational Monitor, 9 , 21-24.

Scott, W. R. (1995). Institutions and Organizations. Sage.

Sharma, S., \& Henriques, I. (2005). Stakeholder influences on sustainability practices in the Canadian forest products industry. Strategic Management Journal, 26(2), 159-180.

Sheth, J. N., Sethia, N. K., \& Srinivas, S. (2011). Mindful consumption: a customer-centric approach to sustainability. Journal of the Academy of Marketing Science, 39(1), 21-39.

Spesard, J. (2019). Tiny house trend: Why so many people are looking to live small. Fox Business. Retrieved January 26, 2020, from https://www.foxbusiness.com/real-estate/tiny-home-pheno mena-the-pros-and-cons-of-living-in-a-micro-home.

St. Clair, D. P., Hunter, G. K., Cola, P. A., \& Boland, R. J. (2018). Systems-savvy selling, interpersonal identification with customers, and the sales manager's motivational paradox: a constructivist grounded theory approach. Journal of Personal Selling \& Sales Management, 38(4), 391-412.
Strang, D., \& Sine, W. D. (2002). Interorganizational Institutions. In Baum, Joel AC (Der), The Blackwell Companion to Organizations, Oxford: Wiley-Blackwell.

Susanka, S. (2009). The not so big house. A blueprint for the way we really live: 10th (anniversary). Taunton.

Tadajewski, M., Chelekis, J., DeBerry-Spence, B., Figueiredo, B., Kravets, O., Nuttavuthisit, K., et al. (2014). The discourses of marketing and development: towards 'critical transformative marketing research'. Journal of Marketing Management, 30(17-18), $1728-1771$.

Thoreau, H. D. (1854). Walden. New Haven, CT: Yale University Press.

Thornton, P. H., Ocasio, W., \& Lounsbury, M. (2012). The institutional logics perspective: A new approach to culture, structure, and process. Oxford University Press.

Unger, N. (2017). Tiny Homes are all the rage. So Why do so few communities welcome them? Washington Post. Retrieved December 18, 2020, from https://www.washingtonpost.com/news/made-byhistory/wp/2017/11/28/tiny-homes-are-all-the-rageso-why-do-sofew-communities-welcome-them.

Vargo, S. L., \& Lusch, R. F. (2016). Service-dominant logic 2025. International Journal of Research in Marketing, 34(1), 46-67.

Vitell, S. (2015). A case for consumer social responsibility (CnSR): including a selected review of consumer ethics/social responsibility research. Journal of Business Ethics, 130(4), 767-774.

Wagner, S. M., Lukassen, P., \& Mahlendorf, M. (2010). Misused and missed use-grounded theory and objective hermeneutics as methods for research in industrial marketing. Industrial Marketing Management, 39(1), 5-15.

WCED, S. W. S. (1987). World commission on environment and development. Our Common Future, 17(1), 1-91.

Publisher's Note Springer Nature remains neutral with regard to jurisdictional claims in published maps and institutional affiliations. 